\title{
The Development of Digital Economy in Indonesia
}

Ahmad Zafrullah Tayibnapis, Lucia E. Wuryaningsih, Radita Gora

Faculty of Business and Economics, Universitas Surabaya Faculty of Pharmacy, Universitas Surabaya

Faculty of Social and Political Sciences, Universitas Satya Negara Indonesia

Perkembangan digital technology yang pesat memiliki peran yang besar dalam bidang ekonomi. Hal ini dapat dilihat melalui bagaimana internet mempengaruhi petumbuhan ekonomi, memperluas kesempatan kerja, serta meningkatkan layanan publik. Dengan begitu, revolusi teknologi digital seharusnya dipandang sebagai kesempatan bisnis baru.

Saat ini dunia mulai memasuki era revolusi industri 4.0 dimana semua hal yang dikerjakan menggunakan teknologi terbarukan yang mampu mengubah seluruh sistem manajemen dalam suatu industri. Perubahan tersebut juga meliputi industri keuangan yang biasa dikenal dengan produknya berupa layanan keuangan dan digital banking.

Layanan keuangan berbasis teknologi cukup berkembang dengan pesat di Indonesia, hal tersebut ditandai dengan mulai bermunculan perusahaan startup yang sebagian besar pembayarannya menggunakan uang digital atau e-money. Perkembangan yang pesat tersebut juga menjadi pertanda bahwa teknologi mampu memainkan peran yang cukup strategis dalam perekonomian Indonesia. Hal tersebut juga selaras dengan keinginan konsumen yang menginginkan layanan yang tidak birokrasi (berbelit-belit).

Produk - produk layanan keuangan digital yang telah berkembang secara pesat di Indonesia adalah sebagai berikut, Internet banking, Mobile banking, AMS perbankan, ATM, E-money, Phone banking, Galeri pembayaran, Perbankan tanpa cabang, Debit online, Outlet digital, Kartu kredit virtual, Sistem manajemen kas, EDC, Cabang seluler, Akun seluler, dan Aplikasi keuangan berbasis smartphone. Produk tersebut disediakan untuk memotivasi pelanggan menjadi lebih loyal dan menjadi bagian dari gaya hidup modern.

Anak-anak generasi $\mathrm{X}$ dan $\mathrm{Y}$ juga cenderung lebih familiar dengan teknologi digital, dimana sekarang tersedia berbagai macam produk digital yang 
memudahkan kegiatan manusia, seperti opsi pembayaran yang lebih baik, jasa antar yang lebih cepat, dan lain-lain.

Di jaman sekarang ini, kebanyakan orang menginginkan hal yang mudah, efisien, dan tidak memakan biaya yang mahal. Survei-survei telah membuktikkan bahwa kebanyakan orang lebih memilih untuk menggunakan teknologi digital karena lebih mudah, efisien, dan murah. Meskipun masih ada beberapa orang yang khawatir akan keamanan teknologi digital. Namun, jumlahnya jauh lebih sedikit daripada mereka yang memilih untuk menggunakan teknologi digital di berbagai bidang.

Perkembangan teknologi digital yang cukup pesat di Indonesia tentunya harus didukung oleh pemerintah. Selain itu, baik perusahaan teknologi digital maupun usaha konvensional seharusnya bekerjasama, seperti dalam sector perbankan, baik perusahaan financial technology maupun bank konvensional seharusnya bekerjasama untuk mendukung dan memajukan sector perbankan di Indonesia. Kebanyakan business start up telah menerapkan strategi ini.

Setelah internet mulai muncul dan masuk kedunia perdagangan, pola perdagangan menjadi berubah secara signifikan. Kegiatan berdagang sangat mudah dan dapat dilakukan hanya dengan menggunakan gadget. Kecepatan dan kemudahan menggunakan internet dalam berbisnis online juga mengubah pola pikir dan perilaku masyarakat. Salah satunya adalah munculnya banyak bisnis baru yang dikembangkan oleh anak muda karena dengan berbisnis online tidak memerlukan modal yang terlalu besar.

Karena perkembangan perilaku masyarakat ini juga, maka UMKM sebagai bentuk usaha yang dominan di Indonesia harus dapat menyesuaikan diri dan mengubah pola bisnisnya sesuai dengan kebutuhan masyarakat. Sejauh ini, 4,6 juta UMKM sudah mendapatkan peningkatan penjualan karena telah merambah ke bisnis online dan pemerintah mentargetkan hal tersebut mencapai 8 juta UMKM pada tahun 2020 .

Namun, hal-hal yang menjadi kendala UMKM untuk masuk ke bisnis online antara lain kurangnya bahan baku yang dapat digunakan untuk proses produksi itu 
sendiri dan kurangnya SDM Indonesia dalam menggunakan teknologi untuk menjalankan bisnis online. Disisi lain, jika telah dapat dilakukan dengan baik, bisnis online dapat meningkatkan ekspor Indonesia selain minyak bumi dan ikut berkontribusi untuk meningkatkan pertumbuhan ekonomi Indonesia sebagai contoh, penjualan batik fashion asal Indonesia yang telah mencapai pasar Amerka dan Eropa karena berjalannya bisnis online.

Singapura, Jepang, dan Inggris merupakan negara - negara yang mampu membuktikan bahwa teknologi keuangan dapat memberikan dampak yang cukup signifikan pada pertumbuhan ekonomi dan stabilitas sistem keuangan. Selain itu, teknologi keuangan juga memberikan kredit berbiaya rendah dalam upaya mendorong daya beli masyarakat. Kehadiran layanan keuangan digital dapat membuat peluang baru maupun menjadi ancaman bagi industri perbankan. Bank harus mempertahankan pelanggan yang sudah menjadi nasabahnya dan berusaha menarik pelanggan baru yang datang dari generasi milenium.

Penting untuk mengerti bahwa pertumbuhan ekonomi Indonesia di masa depan membutuhkan sektor keuangan yang kuat dan stabil pada angka 6\% per tahun. Ini artinya bank, asuransi, pasar modal dan startup perusahaan harus didorong agar pertumbuhan kredit tahunan tidak lagi di kisaran 10-12\%. Hal ini dimaksudkan agar kapasitas sektor keuangan dapat meningkat lima kali lipat dari posisi saat ini, seperti yang telah dicapai oleh Singapura dan Thailand.

\section{Concluding Remarks}

Digital technology is proven to play a strategic role in providing goods and services in a convenient, practical, cheaper, faster, timesaving and labor-intensive way (Tayibnapis, 2018) 
Nama

Rosaline Jeanette S.

Felix Widyadhana

Andy Marvin A.

Daniel Febryan S.

Steven Irawan
NRP

KP

130318114

C

130318115

C

130318133

C

130318137

C

130318139 